\title{
Transborder Capitalism and National Reconciliation: The American Press Reimagines U.S.-Mexico Relations after the Civil War
}

\author{
Alys Beverton* \\ Oxford Brookes University, Oxford, United Kingdom \\ ${ }^{*}$ Corresponding. E-mail: abeverton@brookes.ac.uk
}

\begin{abstract}
The end of the Civil War did not eradicate Americans' concerns regarding the fragility of their republic. For many years after Appomattox, newspapers from across the political spectrum warned that the persistence of sectionalism in the postwar United States threatened to condemn the country to the kind of interminable internal disorder supposedly endemic among the republics of Latin America. This article examines how, from the early 1870 s onward, growing numbers of U.S. editors, journalists, and political leaders called on Americans to concentrate on extending their nation's commercial reach into Mexico. In doing so, they hoped to topple divisive domestic issues-notably Reconstruction-from the top of the national political agenda. These leaders in U.S. public discourse also anticipated that collaboration in a project to extend the United States' continental power would revive affective bonds of nationality between the people of the North and South. In making this analysis, this article argues that much of the early impetus behind U.S. commercial penetration south of the Rio Grande after the Civil War was fueled by Americans' deep anxieties regarding the integrity of their so-called exceptional republic.
\end{abstract}

Keywords: capitalism; Civil War; Reconstruction; sectional reconciliation; U.S.-Mexican relations

On Mar. 11, 1883, a baby was baptized in Monterrey, Mexico. The child was the son of Mexican general Geronimo Treviño and his wife Roberta, the daughter of U.S. Army Commander General Edward O. C. Ord. The ceremony generated a good deal of interest in the American press. The Chicago Tribune, for example, printed a lengthy account of the christening of the "only child known to have been born in wedlock by the cross of Mexican upon American stock"-or rather, the first such child "whose parents had any social or political standing in the Republic of Mexico." This "International Baby," the newspaper continued, symbolized the dramatic improvement in U.S.-Mexican relations over recent years. ${ }^{2}$ In the summer of 1877, General Ord and General Treviño had faced one another on opposite sides of the Rio Grande, their armies at their backs, while newspapers in the United States predicted war. ${ }^{3}$ The standoff had been caused by President Rutherford B. Hayes's decision to allow U.S. soldiers to enter Mexico in pursuit of bandits and Native

(C) The Author(s), 2021. Published by Cambridge University Press on behalf of the Society for Historians of the Gilded Age and Progressive Era (SHGAPE). This is an Open Access article, distributed under the terms of the Creative Commons Attribution licence (https://creativecommons.org/licenses/by/4.0/), which permits unrestricted re-use, distribution, and reproduction in any medium, provided the original work is properly cited. 
American raiders, a unilateral order that Mexican officials viewed as an insulting violation of their national sovereignty. That incident was only the most recent in a series of disputes between the two republics, which for decades had been fighting over trade, taxes, and territory. The fact that by 1883 Treviño and Ord were joined by familial blood reflected how, in the space of six short years, the fraught U.S.-Mexican relationship had blossomed into an intimate partnership of exchange and investment. Better still, their grandchild's godfather was former (and future) Mexican president Porfirio Díaz, the man who many Americans credited with having first opened Mexico's doors to U.S. capital and enterprise.

Some Americans believed that there was more than profit waiting for them in Mexico. Debates over foreign policy toward Latin America-especially the question of territorial expansion-had aggravated tensions between pro- and antislavery advocates in the antebellum United States. ${ }^{4}$ Abolition in 1865 did not resolve all of their disagreements. Still, after the Civil War a near-consensus did emerge in the United States regarding key goals that ought to guide U.S. relations with Latin America, and Mexico in particular-including creating new markets for American exports, expanding U.S. investment in Mexico's mining and agricultural industries, and developing cross-border transportation networks to enable the movement of Mexican minerals and other raw materials into the United States. These aims, which met the economic interests of Americans located in various parts of the Union, elicited a considerable degree of unanimity in an otherwise deeply divided post-Civil War society. That fact was not lost on certain prominent editors, journalists, and political leaders who in the early 1870s began to call for a nationwide effort to extend U.S. financial and commercial influence south of the Rio Grande. A unifying mission of national aggrandizement abroad, they hoped, would help Americans forget the wartime resentments many of them still held toward one another.

Historians have shown that sectional reconciliation was a gradual process that played out on numerous cultural, social, and political fronts throughout the last third of the nineteenth century. ${ }^{5}$ Those who examine the place of international relations and foreign policymaking in this history typically focus on the 1898 Spanish-American War. ${ }^{6}$ To do so is understandable; even at the time, the conflict had clear reconciliationist aspects. President McKinley made a point of naming several ex-Confederate generals to lead U.S. expeditionary forces in Cuba, for instance, and many newspapers at the time reported that a disproportionate number of Southern men had volunteered to defend the Stars and Stripes against the Spanish foe. Part of the war's cross-sectional appeal stemmed from its racial undertones. The end of Reconstruction in 1877 reflected a willingness among white Northerners to abandon the effort to rework Southern society on the basis of racial equality in exchange for improving relations with their white countrymen in the South. Edward Blum argues that one consequence of this shift was the rise of a new "ethnic nationalism" in U.S. society that "assumed deep connections between God's will, whiteness, and American values" and legitimized the relegation of Black Americans to second-class citizenship. ${ }^{7}$ White Americans later invoked these same notions to justify U.S. guardianship over the dark-skinned populations of Cuba, the Philippines, Guam, and Puerto Rico after the 1898 war with Spain. Segregation at home spurred imperialism abroad, and each strengthened white Americans' attachment to a highly racialized national identity.

Current scholarship positions 1898 as the turning point at which domestic reunion, nearing completion, burst forth onto the world stage-reconciliation's "final culmination," as Blum puts it. ${ }^{8}$ This assertion implies that prior to the war with Spain, sectional healing and foreign policymaking in the United States had little to do with one 
another. Numerous studies detail the activities of U.S. merchants, financiers, and businessmen who ventured abroad after the Civil War. As John Mason Hart demonstrates, initially, many of these individuals went to Mexico, where they developed methods of extraction and exploitation that Americans then applied across Latin America, Asia, and Africa later in the century. ${ }^{9}$ Such studies are principally concerned with the small number of Americans who had professional or financial interests abroad, such as merchants, speculators, and bankers. They therefore leave undisturbed the common scholarly assumption that the majority of people in the postbellum United States took little interest in foreign relations. As Brian Schoen argues, following Appomattox, most Americans were focused on "reconstructing the Union from within," while "overseas work would be left-for the most part-to America's new class of financiers and overseas men." ${ }^{10}$ It was not until the 1890s, once the most pressing postwar challenges (namely, the pacification of hostile populations in both the South and West) had been largely resolved, that most people in the United States finally lifted their gaze beyond their borders.

This article takes a different view. Between the early 1860s and the 1880s, it argues, the unfinished task of sectional reconciliation shaped rather than inhibited Americans' interest in foreign relations. To make this case, this study turns to the realm of public opinion as expressed in the U.S. press. During the second half of the nineteenth century, new printing and transportation technologies precipitated the rise of mass-circulation newspapers in the United States. Meanwhile, advances in global communication, such as the laying of cables across the Atlantic Ocean, enabled these publications to receive news from distant corners of the world with growing rapidity. ${ }^{11}$ These advancements enhanced the American press's effectiveness as a form of "representational machinery," a term that refers to the mediums by which a society receives images of foreign peoples, environs, and cultures. $^{12}$ The representations of distant lands that appeared on the pages of U.S. newspapers during this period aimed to cultivate among readers a sense of national distinctiveness and purpose. This purpose was particularly true regarding images of Latin America, which was routinely depicted as a fertile Eden inhabited by childlike primitives who lacked the discipline necessary to make proper use of their abundant natural resources. These representations created a metanarrative that legitimized the penetration of American technology, capital, and manpower into this region as a means to realize its productive potential. ${ }^{13}$

Scholars interested in popular U.S. perceptions of Latin America usually take either the 1840 s and 1850 s or the 1890 s as their period of analysis, those being decades that witnessed heightened U.S. economic, military, or political activity south of the border. ${ }^{14}$ This article instead examines the late 1860 s to the 1880 s-a comparatively subdued period in U.S. hemispheric relations. It would be a mistake, however, to infer from this relative decrease in activity a corresponding lack of interest among Americans in the countries below their border. In the antebellum era, Mexican policy had been a lightning rod for sectional disputes over the extension of slavery. After emancipation, however, certain hemispheric interests rose to the forefront of public consciousness, uniting Texan settlers and Californian miners, New York bankers and New Orleans merchants. These interests included suppressing border raids, reducing tariffs on U.S. goods entering Mexican markets, and developing transborder railroad networks to access Mexico's mining districts. After the Civil War, growing portions of the U.S. press therefore viewed the pursuit of these goals as a potential opportunity for cross-sectional cooperation. 
Political events on each side of the Rio Grande increased Americans' interest Mexico. By the early 1870s, certain influential Northern editors had withdrawn their support for congressional Reconstruction. Their newspapers joined with many Southern publications in calling for the program to end in order to allow meaningful reconciliation between the white sections of U.S. society to take place. These disparate portions of the national press each came to believe that a robust mission to extend U.S. economic interests south of the Rio Grande would distract Americans from fighting over old wartime issues. For much of the 1870 s, this theory went untested largely because political instability in Mexico rendered that country an unappealing environment for U.S. business and investment. After 1876, however, President Díaz inaugurated an era of apparent law and order south of the Rio Grande. The following year, the U.S. federal government recalled its troops from the former Confederate states. What followed was a dramatic surge in American commercial and financial activity in Mexico, propelled by a U.S. press championing sectional reconciliation through national aggrandizement.

Other areas of the world witnessed increased U.S. business and commercial activity after the Civil War. Yet it was Mexico's unique place in the postwar American imagination that gave it special power as a site for sectional reconciliation. The Reconstruction era was a tumultuous time in the United States. The prevalence of violence, corruption, and particularly factionalism led newspapers across the country to make fretful analogies between the United States and the notoriously chaotic Mexico. The supposedly exceptional U.S. republic looked ready to follow its neighbor down a path of endless internal discord. But Mexico also represented the hope of salvation. As many American papers reminded their readers, God had ordained that the United States would be the predominant power of the New World. The pursuit of U.S. economic influence over Mexico, therefore, was a way to reconnect Americans to a providential national mission that predated their transitory sectional disputes. By the early 1880s, as U.S. economic ventures below the Rio Grande started to bear fruit, these publications stopped invoking Mexico as a portent of future chaos and instead began to portray that country as a protégé dutifully following the United States' example toward stability and modernization. This image assured readers that the United States had survived its period of internecine strife and resumed its role as the New World's exemplary republic.

In the summer of 1872 , the Mexican republic seemed to be on the verge of collapse. President Benito Juárez had successfully united his country to fight off the French Intervention of 1862-1867. The departure of the last French troops, however, had been swiftly followed by the reemergence of long-standing regional, ethnic, and ideological divisions in Mexican society. From 1868 onward, the Juárez administration was harassed by partisan intrigues, defiant state governors, and a series of peasant rebellions in the states of Nuevo León, Zacatecas, and Durango. Juárez's efforts to shore up executive power in part to combat these challenges led his opponents to add tyrannical tendencies to their list of grievances against the president. When Juárez scraped a victory in the 1871 presidential election, then-General Díaz, a national war hero, accused him of violating the single term clause of the Constitution of 1857. Díaz then launched a rebellion, hoping to ride popular dissatisfaction with the administration into the National Palace. ${ }^{15}$ 
Most observers in the United States were unimpressed. The New York Herald, one of the country's most widely read newspapers, had developed a grudging respect for the determination with which the Juaristas defended their republic against French imperial aggression during the 1860s. ${ }^{16}$ Yet the Herald's goodwill evaporated when, following Juárez's return to power, reports reached the United States that Mexico had begun to veer between unrest and authoritarianism. "Universal murder," the paper said in 1867 of the once-feted Juárez government, "is the present platform of the dominant party in Mexico." 17 In 1871, the Herald concluded that General Díaz's La Noria rebellion was confirmation that "no stable government is possible" in Mexico. ${ }^{18}$

It was thought, though, that Mexicans' misery might create opportunities for Americans. The New York Herald's founder James Gordon Bennett had been an enthusiastic advocate of Manifest Destiny, the notion popularized in the 1840s that the United States was destined to possess the entire North American continent. ${ }^{19}$ By 1871 , Bennett's son James Gordon Bennett Jr. had inherited his father's newspaper and his enthusiasm for expansion. That winter, the Herald reported that Díaz's rebellion, by causing a breakdown of central authority in Mexico City, had led to a spike in raiding activity in the U.S.Mexican borderlands. The newspaper insisted that President Ulysses S. Grant order U.S. troops to take possession of Mexico's northern states to protect American residents in those regions. With U.S. sovereignty established, the Herald predicted, "forty millions $[s i c]$ of vigorous Americans" would flood into these states, sweeping away their "decaying populations" so that this wasted land could "blossom" under the "strong and progressive" influence of the United States. ${ }^{20}$

Bennett Sr. had viewed territorial growth as a truly national interest and therefore lamented its association with the divisive slavery issue. In 1871, his son likewise insisted that the quest to expand predated-and therefore transcended-Americans' sectional divisions. The New York Herald had been a leading critic of congressional Reconstruction since its advent in 1866-67. Disenfranchising white Southerners and forcing them to live under the supervision of federal troops, the newspaper insisted, only fueled their hostility toward Washington, Republicans, and their Northern countrymen in general. By aggravating the "old conflict between loyalty and disloyalty," the Herald warned in 1868, Reconstruction produced conditions for yet more rebellions that would see the United States devolve into "a Mexicanized territory." 21

The Herald insisted that, instead of meddling in Southern politics, President Grant ought to "bring ... a sharp and decisive issue involving the annexation ... of Mexico" before the American people. ${ }^{22}$ The controversies of Reconstruction would be quickly forgotten amid a "general uprising of the people on the grand idea of 'manifest destiny." 23 At the core of the American character, after all, was an "irresistible impulse" for "territorial aggrandizement." 24 Throughout U.S. history, "national pride" had flourished with each push for "expansion and the grandeur of the country." 25 The post-Civil War era was therefore an auspicious time to launch another effort to extend the country's borders. As the Herald explained, a "new and great national issue like that of the annexation of Mexico ... would arouse popular ambition and fervor" and "put an end to sectional discord, by uniting the whole of the American people-North, South, East and West-in one common object." 26

The proposal met with a cool response among other leading U.S. newspapers. In the antebellum period, some prominent Southern organs had cautioned that territory acquired from Latin America would bring dangerous numbers of non-white peoples into the United States. ${ }^{27}$ As long as slavery was intact, however, there was some assurance that these additions would be safely incorporated into existing racial hierarchies, thus ensuring 
that the United States did not come to resemble those racially hybrid republics below its border. ${ }^{28}$ After the Civil War, however, Southern publications such as the Dallas Daily Herald worried that Reconstruction would "divest our model Republic of every beauty, grace, and virtue, and make it a Mexico." ${ }^{29}$ South Carolina's Fairfield Herald similarly worried that Republican plans to enfranchise Black men would lead to miscegenation and social decay. For proof, Americans needed only to turn to the "examples of Mexico," where "suffrage and mongrelism are most horribly connected." 30 One Tennessee newspaper described these same supposed consequences with more dramatic language: "Mexico and the United States," the Clarksville Chronicle warned, would "clasp hands, across the border" as "twin victims of miscegenation" plagued by "degradation, poverty," and "the worst forms of social vices." 31

Purportedly, acquiring land from Mexico would hasten the realization of these ominous predictions. In 1871, the Philadelphia-based Public Ledger warned against absorbing that country's "mongrel populations" because they would be "joined to the blacks and mulattoes of the Southern States" in alliance over the region's white citizens. ${ }^{32}$ One Louisiana newspaper noted that while the New York Herald's Northern readers might benefit from the bounties to be had from this Mexican territory, Southerners would suffer as "several millions of Mexican Indians" flooded into their states and joined arms with carpetbaggers to strengthen the system of "Negro domination." 33 The Memphis Daily Appeal added that, after taking land from Mexico, President Grant would likely claim that the only way to control its volatile inhabitants was "through compressive and repressive force." ${ }^{4}$ The president would then send troops into Mexico, trailed by a parade of carpetbaggers who would feast upon that defenseless land just as they had the postwar South. Expansion into Mexico, far from ending Reconstruction, would exacerbate its most harmful effects.

The reaction was hardly more encouraging outside the South. The Civil War had cemented an association between territorial expansion, slavery, and disloyalty in Northern public discourse. As the New York Tribune had declared in 1863, slaveholders' dreams of creating a "Southern empire to extend into South America" had fueled their ambitions for independence. ${ }^{35}$ In 1864, the Chicago Tribune similarly condemned Confederate leaders as the same men who had "revolutionized Texas for slavery[,] made war on Mexico for slavery," and "agitated and alarmed the whole world with [their] aggressive zeal for slavery." 36 Many Northern periodicals saw the Union victory in 1865 as an opportunity to forge a new path for U.S. relations with Latin America. "By exterminating slavery," Harper's Weekly asserted, Americans had "extirpated the cancer of "manifest destiny" and done away with the "infinite swagger and bluster of a slavery-propagating policy." "37 By 1871, the San Francisco Chronicle, though disappointed with the course of Mexican politics in recent years, was still adamant that Americans had a duty to "assist our sister republic in the world of development, rather than to annex her." 38

Lofty principle only partly explains these publications' opposition to acquiring land from Mexico. New York Tribune editor Horace Greeley had supported Reconstruction during its critical early months. The revolutionary program, he had told readers in 1867 , was necessary in order to "see our long strife ended ... and the whole land quiet, busy and prosperously pursuing the arts of Peace!"39 But over time, Greeley began to have doubts. In the summer of 1871, the editor toured the South, writing glowing reports of white Southerners' hospitality and contrition that were then published in the Tribune. "I am entirely confident," read one dispatch from Tennessee, that "none know better than the great body of the Southern Whites that the reenslavement of the Freedman is a moral impossibility." 40 Greeley had become convinced that Radical Republicans were 
deliberately exaggerating the extent of opposition to Reconstruction in the South in order to justify continuing to hold that region as an occupied territory. Any hostility that white Southerners displayed, Greeley insisted, was a valid response to the ignominy of living under the rule of federal soldiers and corrupt Reconstruction legislators. "Thousands hate the "carpetbaggers," Greeley explained, but they "do not hate the Union." 41 In his mind, then, Reconstruction increased rather than suppressed rebellious sentiments among white Southerners.

Greeley was not the only one to shift from advocate to critic of Reconstruction. In 1871, a group of reformers, journalists, and politicians met in Cincinnati, Ohio, to launch the Liberal Republican Party. This new organization was supported by several formerly Republican-leaning newspapers, including Horace White's Chicago Tribune. At their 1872 convention, the Liberal Republicans nominated Horace Greeley as their candidate for president. In July, the regular Democratic Party linked its fate to the Liberals by nominating Greeley to head a fusion ticket. ${ }^{42}$ This diverse coalition was in part held together by the belief that Reconstruction undermined the unity of the still-fragile U.S. republic. Much like certain Southern publications, liberal organs drew analogies with Mexico to express this concern. The Chicago Tribune, for example, noted that President Juárez portrayed his "petty quarrels with [political] rivals" as formidable battles against traitorous priests in order to terrify Mexican congressmen into expanding his executive powers. ${ }^{43}$ This was "the same thing in principle" to President Grant's efforts to secure the passage of the $1871 \mathrm{Ku}$ Klux Klan Act by exaggerating the severity of white Southern vigilantism. ${ }^{44}$ The New York Tribune, meanwhile, worried that the United States' drift toward authoritarianism meant that the "model Republic" was setting a "baleful example" for the supposedly inferior self-governing nations south of its border. ${ }^{45}$

President Grant handily saw off the Liberal Republican-Democratic challenge, securing a second term and thus the continuation of Reconstruction. It was in this context that former liberal periodicals considered proposals for the annexation of Mexico's northern borderlands. In June 1872, the Chicago Tribune informed readers of a rumor that Grant, supposedly inspired by the New York Herald, planned to "raise four regiments of troops ... to go to the Mexican frontier" and take possession of several Mexican states. ${ }^{46}$ The newspaper speculated that the idea appealed to Grant's vainglorious and militaristic tendencies. If the plan worked, moreover, the president apparently hoped to fill these new territories' governments with the same class of office-seekers currently occupying the Southern Reconstruction legislatures. "Let the reader imagine the horror," the Tribune shuddered, "of a carpet-bag Government erected in each of the fifty states of Mexico, each Government supported by one or two regiments of troops." ${ }^{47}$ Extending Reconstruction into Mexico would supposedly strengthen its grip at home, and so ensure that the United States slid deeper into factionalism and unrest.

While Reconstruction dampened enthusiasm for territorial acquisitions, some voices in U.S. public discourse began to suggest that alternative forms of aggrandizement south of the Rio Grande might in fact harmonize postwar U.S. society. Initially, most of these emanated from the former Confederate southwest. The Civil War had left the South with many scars, among them torn up railroads, neglected plantations, and state governments deep in debt. During the postwar period, Southern boosters published promotional literature, hosted holiday tours, and organized state fairs to encourage outside investors to sponsor the regeneration of their region's infrastructure and industries. Of primary importance was convincing potential stakeholders-namely, Northern capitalists and Washington legislators - that the postwar South was a safe and welcoming place in which to put their capital. ${ }^{48}$ Boosters also emphasized their region's potential to facilitate access 
to trade and investment opportunities abroad. During the Civil War, fighting in the Trans-Mississippi West had not reached the scale or deadliness of the eastern theaters, nor were the wounds on the region's economy as severe. ${ }^{49}$ Nevertheless, given their proximity to the circum-Caribbean and northern Mexico, areas such as Texas and southern Louisiana were integral to boosters' efforts to demonstrate the commercial potential of the postbellum South as a whole.

During the 1860s, simultaneous crises in the United States and Mexico had generated a lively trade in cotton and war materiel across the shared border. ${ }^{50}$ Peacetime stopped these exchanges, however, and by the end of the decade, certain issues that had previously hindered trade between the two republics had returned in full force. Aside from a brief interlude of continental fraternity between Unionists and supporters of the Juárez government during the French Intervention, nineteenth-century Americans typically viewed Mexico as a dangerous and volatile country-hardly an inviting place to do business. Moreover, despite Mexico's contiguity with the United States, Mexico City was harder to reach for most Americans than London; the only options were an uncomfortable journey by horse over rough land teeming with bandits or a weeks-long voyage on a British steamer that sailed from New York to Veracruz via a series of Caribbean ports. These and other obstacles meant that in the early 1870s, Americans were only minor players in Mexican trade, which was otherwise dominated by Europeans. ${ }^{51}$

Projects to improve access to Mexico via the South were therefore highly attractive to would-be U.S. investors-or so promoters of the Texas and Pacific (T\&P) Railroad believed. In March 1871, Congress awarded a charter to this newly incorporated company to build a railroad from Marshall, Texas, to San Diego, California. ${ }^{52}$ The following year, the company published a pamphlet, The Texas and Pacific Railway: Its Route, Progress, and Land Grants, to advertise the road's profit-making potential. Having enumerated various benefits, the pamphlet emphasized that this "giant trunk line" running just north of the U.S.-Mexican border would eventually "connect with lines projected in Mexico." 53 These feeder roads running from the United States "across [Mexico's] northern frontier" would enable U.S. troops and the Mexican Guardia Rural (or rural guard) to "terminate Indian raiding" in the borderlands. ${ }^{54}$ The lines would also penetrate "the great mineral, pastoral, and agricultural regions of ... Sonora and other populous provinces" in northern Mexico, allowing U.S. industrialists to open mines in these regions and carry their contents back north. ${ }^{55}$

The Panic of 1873 dried up the T\&P Railroad's funds and brought construction to a halt. The following year, the company's president Thomas Scott submitted a bill to Congress requesting federal bonds to enable work on the line to recommence. To distinguish his plea from the many others that flooded congressional railroad committees at the time, Scott emphasized his road's international advantages. A "system of railways, based on English capital," read the memorandum accompanying Scott's bill, "has been inaugurated in Mexico, the line from the city of Mexico to Vera Cruz being completed." 56 It was therefore imperative that the U.S. government support the T\&P Railroad to ensure that the British did not steer the trade of eastern Mexico away from the United States, to which "it properly belong[ed]." 57 This argument was echoed by the line's other advocates, a growing number of whom were located outside of Texas. The New Orleans Chamber of Commerce, for example, supported Scott's bill on the grounds that his road would allow Americans access to the "precious metals" of the "the richest States of Mexico." ${ }^{8}$ It would also give U.S. merchants an advantage over European merchants, "who can neither employ navigable waters nor transitable highways from their ocean coast across the 
mountains to the rich and populous cities of interior Mexico."59 "With such a demonstration of undeveloped values only awaiting the connubial ceremony of intermarriage," the Chamber concluded, "does not your honorable body perceive that in postponing this consummation," it is "depriving the American people of the full fruits, which should not be deferred one day beyond the possibility of completion?"60

The T\&P Railroad also won friends among Southern newspapermen, many of whom measured the project's value in both political and economic terms. In June 1873, the Texas newspaper the Weekly Democrat Statesman, reflecting on Democrats' recent takeover of the state legislature, advised readers that the war against Reconstruction was not yet over. Republicans would continue to "keep up the delusion of Southern barbarity and disloyalty" in the minds of Northern voters, and it was therefore incumbent upon "the people of Texas ... to preserve the peace, to suppress all illegal outbreaks and outrages" in order to deny Radicals an excuse to strengthen federal tyranny over the South. ${ }^{61}$ The T\&P Railroad would be the reward for Texans' cooperation in this plan. As the newspaper explained, if federal legislators agreed to support construction, the road would become an "international route" giving Texans access to "the great body of the rich Mexican trade."62 The resulting boom in cross-border commerce would spur the development of other lines throughout Texas that would "consolidate and unify the State ... into one vast, indissoluble empire," which would do more to "foster an ennobling State pride in the breasts of all [Texans] than even hallowed memories of early Texan history." ${ }^{63}$ In a later article, the Statesman added that the T\&P Railroad would be "used by the people of every section" of the country and would therefore elevate Texas into "the richest, most populous and powerful [state] in the Union." 64 Northerners would learn that they had more to gain from the state's prosperity than from its misery, and so demand the end of Reconstruction in Texas. Once this shift in public sentiment occurred, Texans "need not tremble, even if Grant rattled thunderbolts on the summit of Olympus." 65

By the mid-1870s, prominent politicians were broadcasting this message from the national political stage. In 1876, John C. Brown, the former governor of Tennessee and now vice president of the T\&P Railroad, gave an interview to the New York-based Railroad Gazette in which he confessed that he was "deeply troubled" by the "violence of feeling" that many white Southerners displayed toward the federal government. ${ }^{66}$ The Reconstruction Amendments "are now a fait accompli," Brown insisted. ${ }^{67}$ Terrorizing Black voters and carpetbaggers therefore did nothing but make the South "an uninviting field for investment" to outside capitalists. ${ }^{68}$ Brown urged his fellow Southerners to "lay aside all questions of sectional political strife" and instead "address all their efforts to the improvement of their country." ${ }^{99}$ Courting federal assistance for the T\&P Railroad would be a good place to start. As Brown explained, feeder lines running southward from this trunk road would be a "guarantee of peace" in the borderlands and also carry Mexico's "semi-tropical fruits, sugar, coffee, and many other productions" into Texas. ${ }^{70}$ If they exchanged political violence for economic collaboration, Brown advised, Southerners would become both the primary beneficiaries and the managers of U.S.-Mexican trade.

In certain respects, Brown's thinking echoed that of the Bourbon elements of the Southern Democracy. These politicians were at the forefront of the Redemption movement of the mid-1870s. Though willing to benefit from white paramilitary violence to secure office, most Bourbons believed that white Southerners must eventually accept certain realities of the post-emancipation era. Only then would Washington legislators end federal control over the former Confederate states and invest in their economic modernization. ${ }^{71}$ Like Brown, some Bourbons held up continental commercial hegemony as a reward to white Southerners for their cooperation in this strategy. James 
Throckmorton was ousted from the governor's mansion in 1867 for obstructing the rollout of military reconstruction in Texas. When he returned to politics as a congressman in 1876 , however, he was calling on white Southerners to collaborate with federal power. ${ }^{72}$ "How long," he asked his Southern colleagues in the House, "will you refuse to aid yourselves ... because of your ancient prejudices against the policy of the Federal Government?" ${ }^{33}$ Throckmorton advised them to reflect on what this obstinacy cost them. Mexico possessed "many of the oldest and richest mines" in the world, he asserted, most of which were "unworked for want of proper machinery to exhaust the water. ${ }^{74}$ "What a field for American enterprise and capital is here," Throckmorton remarked, and the only way to access it was through the South. ${ }^{75}$ Conciliation with Washington would secure the federal funds needed to connect Texas to the "northern states of Mexico," and from there transform the whole South "into a busy hub of continental trade."76

Advocates of other Southern infrastructure projects also claimed to hold a special advantage in opening up continental trade. Delegates to the 1869 Southern Pacific Railroad Convention insisted that their line would "attract numerous feeders from the neighboring Republic of Mexico." 77 This would open "the great mineral resources of Arizona and Sonora" to U.S. industries while rendering "more valuable the great stock raising districts of Texas, New Mexico, and Northern Mexico."78 In 1870, the Southern Commercial Convention requested federal funds to improve the harbors of the Mexican Gulf states on the grounds that these ports were vital centers of "Mexican trade" where Southern exports have "always found, and must forever in the future find, [their] outlet to the sea." 79 Boosters up and down the Mississippi River also touted their various initiatives' continental connections. In 1874, for example, the Missouri newspaperman Logan U. Reavis was promoting the St. Louis, Iron Mountain, and Southern Railway, projected to run through "Galveston, New Orleans, and Mobile" and extend "to the city of Mexico." ${ }^{80}$ Reavis insisted that the road would bring "a unity of purpose, nature and art" to U.S. society by contributing "to the destiny of our people" to hold commercial sway over the continent. ${ }^{81}$ Boosters often insisted that their particular locality provided the best access to Mexican trade. Collectively, however, they created an image of the South as the key to accessing the riches that lay below the border.

Publicists and politicians, meanwhile, presented continental commercial hegemony as a reward for white Southerners' moderation on the issue of Reconstruction. Sometimes the message came from Republican publications located in the South. The New Orleans Republican noted in 1876 that the Mississippi region ought to be the "center of the whole tropical intercourse" of the hemisphere. ${ }^{82}$ To achieve this, however, the underdeveloped Mississippi Valley needed attention, and this could only be done once outside investors believed that the postwar South was fully pacified. "The State of Louisiana," the Republican explained, "requires nothing more than social order and total abstinence from party politics to make her the most prosperous part of the Union." 83 Certain Southern Democratic organs, particularly those based in urban and industrial centers, made similar arguments. De Bow's Review, for example, reasoned that outside capital was vital if Southern transportation networks were ever to reach "the trade of Mexico and ... the southern tropics," which were "among the most rapidly growing in the world." 44 Accepting Northern and federal aid, therefore, was a tactical move in a wider strategy to see the South "gain recognition and appreciation" as the nation's "connecting link to the trade of the hemisphere." 85

Other sectors of the national press also began to take an interest in Mexico. In 1874, the New York Tribune still believed that Reconstruction was a "foolhardy enterprise" that whipped up Americans' worst "passions and prejudices." 86 Washington legislators, the 
newspaper insisted, would do better to focus "on the regeneration of [the South's] economy" than "meddling with its politics." 87 Only by doing so could they encourage former Confederates to look upon the federal government "not as an enemy ... but as a generous benefactor" and so foster a "unity of interest" among the American people that would "restore the ancient good-will and esteem between the different sections of the Union." 88 The Tribune acknowledged that some Republican Southern legislatures had channeled revenue into local infrastructure projects, but it added that these monies were usually either insufficient or misspent. ${ }^{89}$ Meanwhile "sectional prejudice" prohibited Northern financiers from investing in "any honest program for [Southern] States' improvement," choosing instead to focus "their energies westward" meaning that "we have a multitude of railroads running east to west" and "hardly any ... north to south." 90

Some impetus was needed to draw capital southward. The New York Tribune wondered if Americans would "invest more in the Southern States" if they viewed doing so as part of a larger mission to "open up the commerce of the continent." 91 The Chicago Tribune had a similar notion. "What trade there is to be had from Mexico," the newspaper remarked in 1873, “... is currently controlled by the Europeans." 92 This statement was no exaggeration. Between 1872 and 1873, Great Britain, France, and Prussia received 56.7 percent of Mexico's exports and together made up 64.8 percent of its imports, compared with the American share of 36.1 percent and 25.7 percent, respectively. ${ }^{93}$ That Mexican trade was dominated by Europeans was, the Chicago Tribune insisted, "against the natural law of proximity, against the sympathies inspired by similar political institutions." 94 To establish the United States as the "purveyor of commerce on this continent," Americans needed to invest in "the development of railroads and other means of travel in the South." ${ }^{95}$ Furthermore, a "bold venture to assert our nation's influence on the continent" would reawaken Americans' national pride, lessen the appeal of sectionalism, and so take "political trump cards out of the hands of gambling politicians" who played on tired wartime divisions to lever themselves into office. ${ }^{96}$ Through foreign aggrandizement, in short, Americans could combat "the evils" of factionalism that had plagued them since the Civil War. ${ }^{97}$

Despite growing interest from large portions of the national press, plans to expand U.S. commercial and business activity in Mexico went largely unrealized throughout the first half of the 1870s. Having survived the La Noria rebellion, President Juárez died of a heart attack in July 1872. His successor Sebastián de Tejada was mindful of the warnings made by certain members of his party that closer ties with the United States would court a "peaceful invasion," whereby Yankees would strip Mexico of its resources and economic autonomy. While in office, Tejada therefore canceled numerous contracts with U.S. business interests, including his decision in 1875 to rescind concessions to all American railroad companies in Mexico except the New York-based Mexican National Railroad Company. ${ }^{98}$ Throughout Tejada's presidency, in short, mutual suspicion and prejudices continued to hamper U.S.-Mexican economic relations.

In 1876, political events on both sides of the border began to change the situation. In November, the U.S. presidential contest between Republican Rutherford B. Hayes and Democrat Samuel J. Tilden resulted in an impasse. Each party accused the other of manipulating the returns in Oregon, Florida, South Carolina, and Louisiana and claimed these states for their respective candidate. Gregory Downs shows that during the following months, a trope emerged in U.S. public discourse that held that the United States had been "Mexicanized" and was doomed to follow Mexico into a spiral of civil wars. ${ }^{99}$ In fact, this discourse of "Mexicanization" echoed the analogies with Mexico made by various American newspapers throughout the Reconstruction era. The Democratic Memphis 
Daily Appeal pronounced that Republican intrigues during the 1876 election were merely a continuation of their wider Reconstruction agenda to "Mexicanize our country" by placing it "under the rule of the minority, enabled to retain power by fraud, backed up by the bayonet." 100 Republicans, meanwhile, understood "Mexicanization" as political violence from below rather than above. As the New Orleans Republican reminded readers, since the Civil War, the "grossest intimidation and fraud have been practiced in some of the Southern States." ${ }^{101}$ White Southerners' shameful tactics on polling day in November 1876 were only the most recent evidence of their predilection for antidemocratic violence. ${ }^{102}$ "The Democrat party has rebelled once against the verdict of the people ...," the newspaper concluded. "[T]he people want no more attempts to Mexicanize the country." 103

Despite their differences, these "Mexicanization" discourses each centered on the notion that Reconstruction was driving factionalism in U.S. politics to dangerously high levels. The proudly politically independent journal The Nation articulated this sentiment well in a December 1876 editorial. Positioned above the partisan fray, the publication surmised that both parties had committed wrongdoings in the recent presidential election, but that these were only symptoms of a more insidious disease. As the journal explained, "Mexicanization ... in its earlier stages" manifests "in a change in the political habits and political outlook of the people." 104 Years of division-begun in the antebellum era, climaxing in the Civil War, but then tragically perpetuated throughout Reconstruction-meant that Americans had grown accustomed to "treating the political party opposed to [their] own as a band of criminals or conspirators against the Government."105 They had also learned to tolerate all kinds of villainy on the part of their preferred candidates, so long as it kept the hated opposition out of power. The result was that Americans had lost "familiarity and respect for certain forms and processes and principles" that had been the bedrock of their peaceful, well-ordered government in the past. ${ }^{106}$

The resolution of the election crisis in early 1877 pleased The Nation in two respects. First, Democrats acceded to a Hayes victory, allowing for a peaceful presidential inauguration in March 1877. Second, upon taking office, President Hayes recalled federal troops from the South, thereby bringing formal Reconstruction to an end. "The Negro will disappear from the field of national politics," The Nation cheered, "henceforth the nation, as a nation, will have nothing more to do with him." 107 Other papers met the news with similar relief. "Te Deum laudamus!" the Chicago Times declared. "[A]t last the civil war is over ... after sixteen years of strife and commotion ... peace again spreads [its] wings over the American nation." 108 Finally, Americans could "rest from the turmoil of war and war politics, which the demagogues of partyism" had perpetuated for their own "personal fortunes and political ambition." 109 The Public Ledger, meanwhile, pronounced that "the country has passed through a period of great and protracted excitement," and though the "strain was so great that serious apprehensions filled many minds of the safety and strength of our institutions ... the crisis has passed."110

Yet there was a cautious undertone to these celebrations. Washington, DC's National Republican reminded readers that ending Reconstruction was only the first step in Americans' longer journey to reach a point at which they were able to "rise above the prejudices which bind them to the one side or the other." 111 The next stage was for Southerners to "act in harmony with the Republican party in building up the country and restoring the relations of good-will and accord between the sections." 112 The Chicago Tribune also warned that the hard work of reconciliation still lay ahead. Certainly, President Hayes had signaled that the "people of the North desire nothing better than 
to assist their Southern brethren." 113 Now it was necessary to remind the citizens of each section that they shared a "glorious future of reunited destinies and hopes," and convince them to "forget everything else but that they are Americans." 114 Removing sources of sectional resentment meant little unless it was followed by the active rebuilding of bonds of nationality among the people of the United States.

Mexicans, meanwhile, were weathering their own political crisis. In January 1876, President Tejada decided that he would run for a second term in office. Echoing events four years earlier, the announcement prompted General Porfirio Díaz to raise another rebellion. This time, he was successful. By November, rebel forces had taken Mexico City and installed Díaz in the National Palace. In the United States, most major newspapers advised President Hayes to withhold recognition of the new Mexican government. "Díaz is President," the New York Times cautioned, only until "some one raises a larger and better army." 115 But this Mexican president would soon prove his staying power. Díaz's style of governance represented a technocratic turn in the Mexican liberal tradition that emphasized economic development as the cure to social ills. His domestic agenda therefore included curbing democratic political participation, which he viewed as a source of partisan wrangling and popular unrest. Díaz also used extraordinary executive powers to direct the development of Mexico's transportation networks, diversify its industries, and enlarge its foreign trade. All of these measures, Díaz and his followers believed, would integrate Mexico's fractured society and give employment to those indigent members who were typically drawn into revolutions. ${ }^{116}$

Mexico, however, lacked capital. Díaz therefore needed to enlist foreign stakeholders to help him realize his vision. Unlike his predecessors, Mexico's new president believed that the United States ought to be one of Mexico's closest economic partners. It was therefore unfortunate for Díaz that his rise to the presidency precipitated a sharp downturn in U.S.-Mexican relations. His rebellion sent Tejada's government into disarray, triggering a rise in raiding activity along the border with the United States. Hayes responded by authorizing U.S. troops to chase raiders into Mexico; Díaz increased his forces along the frontier as a show of force in return. ${ }^{117}$ Thankfully, the crisis passed without military conflict, meaning that Díaz was then free to make a series of high-profile gestures designed to win Washington's favor, including abolishing the Zona Libre and making payments on long-standing claims that the Mexican government owed to American residents- “suspicious signs," one Texas newspaper remarked, that Díaz aimed to inaugurate "a new era in the relations of the sister republics of North America."118

The new president also began to issue generous land grants and subsidies to U.S. railroad companies seeking to build in Mexico. In Sonora, a region of extraordinary mineral productive potential, Díaz granted a concession to the Sonora Railway Company, a subsidy of the U.S. Atchison, Topeka, and Santa Fe Company, to build a railroad across the state from the U.S. border to Guaymas. He also subsidized the construction at a rate of 9,000 pesos per kilometer of track built. Concessions to other U.S. railroad companies followed: between 1876 and 1881, Díaz awarded American railroad companies five concessions for over 2,500 miles of track and subsidies amounting to \$32 million. Many of these lines traversed Mexico's northern frontier, connecting remote border towns in the east and the Sierra Madres in the west to central Mexico. ${ }^{119}$ That same year, the Texas and Pacific Railroad connected to the Southern Pacific at Sierra Blanca, Texas, and completed a line from Shreveport, Louisiana, to New Orleans. ${ }^{120}$ The railroad systems of both northern Mexico and the U.S. Southwest were consolidating at a rapid pace.

Improvements in borderlands transport allowed U.S. mining impresarios to extend their operations into San Louis Potosi, Coahuila, Chihuahua, Sonora, Durango, and other 
parts of northern Mexico. In the case of the Sierra Mojada range in southern Coahuila, for example, the discovery of lead and silver in 1878 brought an onrush of American miners who rapidly transformed the virtually abandoned region into a hub of extraction producing 1,000 tons of ore per week. ${ }^{121}$ Cross-border railroads also facilitated the movement of U.S. products southward, particularly manufactured goods into Mexico's urban centers. In the 1870 s, U.S. exports to Mexico were around $\$ 6$ million; they rose to $\$ 11$ million in 1881 and $\$ 15$ million in $1883 .{ }^{122}$ Of even greater importance was the growth of U.S. investment south of the border. As Americans grew confident about Mexico's economic prospects, they channeled more funds into its railroad, mining, agribusiness, and manufacturing industries. Immediately after the Civil War, U.S. investment in Mexico had been only a few million; by the $1880 \mathrm{~s}$, it had risen to roughly $\$ 100$ million. ${ }^{123}$

Certain American newspapers had long been predicting that expanded transborder exchanges would stimulate new lines of communication within the United States. As one New Mexico paper had put it in 1877, transporting Mexican products throughout the United States would connect "the trade of the South" with the "trade of New York, Philadelphia, and Baltimore," creating bonds of "commercial and political sympathy between the people of the North and South" that would "complete the beneficial policy of reconciliation begun so successfully by President Hayes." 124 By the 1880s, these predictions were apparently being realized. "Mexico trade," one Mississippi newspaper reported in 1881, "has given a fresh impetus to business" in New Orleans and the surrounding area, which "is spreading in every direction, and sections that never patronized the city before are now buying largely from it." 125 The Dallas Daily Herald, meanwhile, enthused that each road connecting Texas to the "wealth of Mexico" was an international "highway" from which "the whole country can hope to reap the same great benefits," and from there engage in new forums for cross-sectional collaboration. ${ }^{126}$ As evidence, the news Herald paper pointed to the recent creation of a congressional lobby consisting of delegates "from Louisiana, Texas, California, Colorado, Oregon and other sections interested in looking to general appropriations ... for deepening the water on our gulf coast."127 "Jealousies between the delegations of different States," the newspaper happily reported, were forgotten in recognition that their "common interest beget a Union powerful enough to accomplish its ends." 128

Newspapers also claimed that chasing profits in Mexico was rekindling Americans' sense of national purpose. Early in his first term, Díaz dispatched agents to the United States to launch a public relations campaign to improve American opinions of Mexico. These propagandists employed various tactics to achieve their goal, among them convincing the American public that the United States was the model that inspired Díaz's program for Mexican economic regeneration. As Manuel María Eutimio de Zamacona y Murphy told the New York Herald in 1878, Mexico's president wished to learn from the United States, "whose power he understands and appreciates." ${ }^{29}$ Many U.S. newspapers were pleased by such flattery. President Díaz, the Chicago Tribune noted approvingly, is "a man who is familiar with the United States, who knows our greatness and resources ... and who is familiar with our public men and public policy."130

What most impressed these publications was that Díaz had learned from the United States that economic progress-rather than political experimentation-was the surest way to unify a divided population. As the New York Herald explained, Díaz understood that employment would cultivate Mexicans' "desire for stable government and steady business, instead of bad government and frequent revolutions." ${ }^{131}$ Given that social order was an essential precondition for a functioning democracy, moreover, these newspapers 
applauded Díaz's leadership as facilitating Mexico's gradual evolution toward stable republicanism. "The process ... must be slow," the Milwaukee Daily Sentinel surmised, "but that a start has been made toward securing so desirable a result is a great point gained."132

By the 1880s, signs of significant changes in Mexico were beginning to appear. In the winter of 1878-79, General Treviño launched a rigorous pacification campaign against Native Americans and cattle thieves in Mexico's northern frontier. The ongoing expansion of the country's railroad network further enhanced government's control over the region, which facilitated the movement of troops to quell disturbances not only along the border but in other remote parts of the country as well. In 1877, Mexico had only 570 kilometers of railroad; by 1885 , the network covered 6,000 kilometers. Trains also expanded the country's domestic markets by increasing mobility in both people and products and bringing down regional trade barriers. ${ }^{133}$ Under Díaz's guidance, it seemed, Mexico was fast becoming the United States' exemplary protégé.

In November 1880, the Chicago Tribune recalled that people in the United States had once believed that the "absorption of Mexico by the American Union was inevitable."134 Now, however, Americans were applying a different method of aggrandizement toward its southern neighbor, evident in the "grand system of railway transportation" crossing "the Rio Grande, and, penetrating by various routes ... every part of Mexico." ${ }^{35}$ This, the Tribune declared, was "manifest destiny" for the modern age, whereby the United States improved Mexico "not by taking her territory and incorporating it into the American Union, but by teaching Mexico and giving her the means to strengthening herself by the introduction of trade and commerce." 136 The United States would, in short, "Americanize the Mexicans without denationalizing Mexico."137

References to "Americanization" were becoming a common trope in U.S. public discourse by the early 1880 s. Some publications used the term to refer to the actual migration of U.S. entrepreneurs, laborers, and tourists south of the border. ${ }^{138}$ But many more conceived of "Americanization" as a cultural phenomenon whereby Americans used economic influences to teach Mexicans habits of consumerism, industry, and modernity. Such methods satisfied those Northern periodicals that had hoped that the post-emancipation United States would embrace pacific modes of hemispheric aggrandizement. It also appealed to Southern organs whose enthusiasm for territorial expansion had vanished along with slavery. As the Dallas Daily Herald remarked, "Mexico with its old habits of life, modes of thought and methods of business, could never be a part of the United States in anything but in name."139 "But Mexico Americanized ... waked up to the rush of latter day enterprise, inventiveness and liberality, would even under a separate government be essentially one with this country in purpose and in destiny." ${ }^{140}$ This new Manifest Destiny offered Americans continental hegemony without the risks of amalgamation.

Some newspapers predicted that the United States would soon spread its renovating influence even further afield. "Mexico's success under American influences," the Chicago Tribune declared, must be repeated "throughout the southern portions of the hemisphere." 141 If we "extend our commerce ever further southward," Americans could teach the "weaker republics, modelled after our own, the benefits ... of domestic peace and industry." 142 The New York Herald agreed. "The Monroe Doctrine must be readjusted to the modern times in which we live," that newspaper asserted, and become "a means of spreading America's commercial influence in the name of industry, law, and order." 143 This is not to suggest that there was an absolute consensus in the national press regarding the precise form that U.S. hemispheric policy ought to take. Most major papers did insist, 
however, that henceforth the United States should enhance its influence over its neighbors primarily through economic means. "We will teach them industry," the Chicago Tribune declared in 1881, "and with that ... the blessings of peace and harmony." ${ }^{44}$ In doing so, Americans would transform those "chaotic nations into fine republics like our own." 145

Whether these publications were sincere in their claims that stable republicanism was on the horizon south of the Rio Grande is difficult to know for certain. Nevertheless, what is significant is that they felt the need to make such assertions. By framing economic expansion into Mexico as a continuation of the United States' historic republican mission, these newspapers assured readers that their nation had regained its standing as the world's most successful self-governing democracy. It was a powerful message to communicate to postwar Americans, many of whom had once feared that their so-called exceptional republic might never recover from its devastating civil war and was doomed to follow Mexico and the other Latin American nations into perpetual strife.

After attending his godson's christening at Monterrey, Mexico, in March 1883, former president Porfirio Díaz embarked on a three-month tour of the United States. His route read like a roadmap of the nation's burgeoning postwar industrial and commercial centers. The journey began in New Orleans, where merchants impressed their Mexican guest with a tour of warehouses filled with stock ready to be shipped into the Gulf of Mexico. Díaz then boarded a special carriage provided by railroad magnate James Sullivan that carried him through the hub towns of Galveston, Brownsville, and Laredo, where the Texan trunk lines connected with branch roads running southward over the Rio Grande. Next, he traveled north to New York via St. Louis and Chicago to visit the factories that flooded Mexican markets with finished goods. Díaz's tour ended in Washington, DC, where he met with President Chester A. Arthur and received a formal welcome from the U.S. Congress. At every stop, the former president was praised by the local press as a visionary, the deliverer of the Mexican republic. Díaz's visit to the United States, furthermore, was taken as affirmation that the United States was both the sponsor and the model of Mexico's remarkable transformation. ${ }^{146}$

This notion was a relatively recent phenomenon in postbellum U.S. public discourse. As we have seen, prominent American publicists and political leaders had been troubled by the persistence of sectionalism in their nation's postwar political culture. In their more pessimistic moments, some had invoked Mexico's image as an anarchic, miserable republic to warn their countrymen of the condition into which the United States was sliding. While this image reflected Americans' insecurities about disunity in their republic, however, Mexico itself offered a means to reverse this deleterious trend. U.S. newspapers and journals argued that a collective effort to extend the United States' commercial reach into Mexico would unify U.S. society by distracting Americans from divisive domestic issues and subsuming their lingering sectional antipathies in a spirit of patriotic fervor. A powerful force behind Americans' growing interest in continental commercial aggrandizement, therefore, was widespread anxiety over the fragility of the post-Civil War U.S. republic.

Mexico's function as a unifying tool was symbolic as well as literal. During Díaz's first term, significant portions of the U.S. press insisted that, by contributing to Mexico's economic development, Americans were also assisting in that country's social and political stabilization. Díaz never intended for his regime to become a fully democratic 
one. American publications, however, insisted that by following the United States' example, Mexicans were unifying the discordant elements of their society and so laying the foundations for the future development of a stable representative democracy. The process would be slow; Mexico's internal divisions were more deeply entrenched than those in the United States, and it would take time for economic forces to complete their work. Nevertheless, by the early 1880s, American newspapers proudly declared that the United States now stood as the guide for the eventual success of Mexico's republican experiment. Mexico's image in U.S. public discourse, previously an ominous portent of what the United States might yet become, now reassured Americans that their nation had recovered its standing as the New World's exceptional republic.

Acknowledgments. I thank the two anonymous reviewers whose careful reading and constructive feedback immeasurably improved this article.

\section{Notes}

1 "Mexican Scenes: The International Baby and the Part It Plays in Mexican Politics," Chicago Tribune, Mar. $11,1883,1$.

2 "Mexican Scenes," 1.

3 See for example "Indignant Mexico: The Orders to Ord Makes the Blood of the Greasers Boil," Daily Constitution (Atlanta, GA), July 7, 1877, 1; "Mexico Hostile: Not to Help Order," New York Tribune, July 17, 1877, 1; and "Mexico: Threatening Condition of Affairs," Chicago Tribune, Nov. 25, 1877, 5.

4 The literature on this is vast and still growing. For just a few of the best examples, see Walter Johnson, River of Dark Dreams: Slavery and Empire in the Cotton Kingdom (Cambridge, MA: Belknap Press of Harvard University Press, 2013); Matthew Karp, This Vast Southern Empire: Slaveholders at the Helm of American Foreign Policy (Cambridge, MA: Harvard University Press, 2016); and Robert E. May, Slavery, Race, and Conquest in the Tropics: Lincoln, Douglas, and the Future of Latin America (Cambridge: Cambridge University Press, 2013).

5 Reconciliation historiography is too large and varied to be summarized in a single footnote. I will therefore offer just a handful of the standout works in the field. On Civil War memory, see David W. Blight, Race and Reunion: The Civil War in American Memory (Cambridge, MA: Harvard University Press, 2001); and Caroline E. Janney, Remembering the Civil War: Reunion and the Limits of Reconciliation (Chapel Hill: University of North Carolina Press, 2013). On how concepts of economic progress-particularly among New South "boosters" - facilitated reconciliation between North and South, see Edward L. Ayers, The Promise of the New South: Life after Reconstruction (New York: Oxford University Press, 1992); and Michael W. Fitzgerald, Reconstruction in Alabama: From Civil War to Redemption in the Cotton South (Baton Rouge: Louisiana State University Press, 2017). For a study of how Western settlement shaped sectional reunion, see Heather Cox Richardson, West from Appomattox: The Reconstruction of America after the Civil War (New Haven, CT: Yale University Press, 2007).

6 See for example Edward J. Blum, Reforging the White Republic: Race, Religion, and American Nationalism, 1865-1898 (Baton Rouge: Louisiana State University Press, 2005), 212-43; Amy Kaplan, "Black and Blue on San Juan Hill," in Cultures of United States Imperialism, ed. Amy Kaplan and Donald E. Pease (Durham, NC: Duke University Press, 1993), 219-36; John Oldfield, "Remembering the Maine: The United States, 1898, and Sectional Reconciliation," in The Crisis of 1898: Colonial Redistribution and Nationalist Mobilization, ed. Angel Smith and Emma Davila-Cox (Basingstoke, UK: Macmillan Press Ltd., 1999), 45-64; and Nina Silber, Romance of Reunion: Northerners and the South, 1865-1900 (Chapel Hill: University of North Carolina Press, 1993), 159-96.

7 Blum, Reforging the White Republic, 218.

8 Blum, Reforging the White Republic, 235.

9 John Mason Hart, Empire and Revolution: The Americans in Mexico since the Civil War (Berkeley: University of California Press, 2002). See also Janice Lee Jayes, The Illusion of Ignorance: Constructing the American Encounter with Mexico, 1877-1920 (Lanham, MD: University Press of America, 2011); David M. Pletcher, The Diplomacy of Trade and Investment: American Economic Expansion in the Hemisphere, 1865- 
1900 (Columbia: University of Missouri Press, 1998), 80-113; and William Schell Jr., Integral Outsiders: The American Colony in Mexico City, 1876-1911 (Wilmington, DE: Scholarly Resources Inc., 2001).

10 Brian Schoen, "The Fates of Republics and Empires Hang in the Balance: The United States and Europe during the Civil War Era," OAH Magazine of History 27, no. 2 (Apr. 2013): 45. The same assumption is implicit in the scarcity of diplomatic and transnational studies of the late 1860s and 1870s. Jay Sexton provides a useful discussion of this in "Toward a Synthesis of Foreign Relations in the Civil War Era, 18481877," American Nineteenth Century History 5, no. 3 (2004): 50-73.

11 Richard L. Kaplan, Politics and the American Press: The Rise of Objectivity, 1865-1920 (Cambridge: Cambridge University Press, 2002), 72-139.

12 Stephen Greenblatt, Marvelous Possessions: The Wonders of the New World (Chicago: University of Chicago Press, 1991, 2017), 4.

13 For more on how nineteenth-century Americans constructed representations of the hemisphere, see Gilbert M. Joseph, Catherine C. Legrand, and Ricardo D. Salvatore, eds., Close Encounters of Empire: Writing the Cultural History of U.S.-Latin American Relations (Durham, NC: Duke University Press, 1998); Amy Kaplan, The Anarchy of Empire in the Making of U.S. Culture (Cambridge, MA: Harvard University Press, 2002); and Amy Kaplan and Donald E. Pease, eds., Cultures of United States Imperialism (Durham, NC: Duke University Press, 1993).

14 In addition to the above, see Reginald Horsman, Race and Manifest Destiny: The Origins of American Racial Anglo-Saxonism (Cambridge, MA: Harvard University Press, 1981); Matthew Frye Jacobson, Barbarian Virtues: The United States Encounters Foreign Peoples at Home and Abroad, 1876-1917 (New York: Hill and Wang, 2011); and Robert W. Johannsen, To the Halls of the Montezumas: The Mexican War in the American Imagination (New York: Oxford University Press, 1985).

15 Guy P. C. Thompson with David G. LaFrance, Patriotism, Politics, and Popular Liberalism in NineteenthCentury Mexico: Juan Francisco Lucas and the Puebla Sierra (Wilmington, DE: Scholarly Resources Inc., 1999), 183-200.

16 For more on Americans' sympathy for Mexican liberals during the French Intervention, see Marvin Goldwert, "Matias Romero and Congressional Opposition to Seward's Policy toward the French Intervention in Mexico," The Americas 22, no. 1 (July 1965): 22-40; and Patrick Kelly, "The Lost Continent of Abraham Lincoln," Journal of the Civil War Era 9, no. 2 (June 2019): 223-48.

17 "Mexico and the United States-The Duty of Congress," New York Herald, July 5, 1867, 4.

18 "More Mexican Anarchy and Depredations-The Duty and Opportunity of General Grant," New York Herald, June 5, 1872, 6 .

19 James L. Crouthamel, Bennett's New York Herald and the Rise of the Popular Press (Syracuse, NY: Syracuse University Press, 1989), 56-68.

20 "Mexico and the United States," New York Herald, July 5, 1867, 4.

21 "The Present Crisis and the Future of the Democracy," New York Herald, Oct. 7, 1868, 6.

22 "Cuba and Mexico, or Either-General Grant's Great Opportunity," New York Herald, Jan. 10, 1872, 6.

23 "Cuba and Mexico," 6.

24 "The Revolutionary War in Mexico-Interposition of the United States Necessary," New York Herald, Feb. 17, 1872, 6 .

25 "The Revolutionary War in Mexico," 6.

26 "General Grant's Position and Opportunity-Territorial and Commercial Expansion the Policy," New York Herald, Dec. 18, 1871, 6.

27 For a useful study of how racial prejudices both spurred and inhibited expansionism in the antebellum United States, see Horsman, Race and Manifest Destiny, 79-249.

28 For more on U.S. slaveholders' views of emancipation in the Spanish American republics, see Paul D. Naish, Silence and Slavery: Latin America and the U.S. Slave Debate (Philadelphia: University of Philadelphia Press, 2005).

29 "Kentucky," Dallas Daily Herald, Aug. 15, 1868, 2.

30 "Miscegenation," Fairfield (SC) Herald, July 13, 1870, 2.

31 "Coolie Labor," Clarksville (TN) Chronicle, July 23, 1870, 2.

32 "Mongrel Progress," Public Ledger (Philadelphia), Dec. 8, 1871, 2.

33 "Mexico," Bossier (LA) Banner, Sept. 14, 1872, 2.

34 Memphis Daily Appeal, Aug. 12, 1872, 1. 
35 "The French Conquest of Mexico," New York Tribune, July 28, 1863, 4. There was some truth to the Tribune's claim. Indeed, historians have revealed clear connections between Southern separatism and expansionist ambition. See for example Adrian Brettle, Colossal Ambitions: Confederate Planning for a Post-Civil War World (Charlottesville: University of Virginia Press, 2020); Johnson, River of Dark Dreams; and Karp, Vast Southern Empire.

36 "What the Rebels Fear," Chicago Tribune, Jan. 7, 1864, 3.

37 "Cowell Lending a Hand," Harper's Weekly (New York), Mar. 25, 1865, 178.

38 "Mexico and Annexation," San Francisco Chronicle, July 11, 1873, 2.

39 "The Issue," New York Tribune, Oct. 25, 1867, 4.

40 Horace Greeley, Mr. Greeley's Letters from Texas and the Lower Mississippi: To Which Are Added His Address to the Farmers of Texas and His Speech on His Return to New York (New York: Tribune Office, 1871), 38.

41 Greeley, Mr. Greeley's Letters from Texas, 41.

42 Andrew L. Slap, The Doom of Reconstruction: The Liberal Republicans in the Civil War Era (New York: Fordham University Press, 2006), 108-98.

43 "Mexico," Chicago Tribune, July 10, 1871, 2.

44 "Mexico," 2.

45 "Mexico," 2.

46 "Another Mexican War," Chicago Tribune, June 28, 1872, 4.

47 "Another Mexican War," 4.

48 For more on Southern boosterism, see Ayers, Promise of the New South; Reiko Hillyer, Designing Dixie: Tourism, Memory, and Urban Space in the New South (Charlottesville: University of Virginia Press, 2014); William A. Link, Atlanta, Cradle of the New South: Race and Remembering the Civil War's Aftermath (Chapel Hill: University of North Carolina Press, 2013); and K. Stephen Prince, Stories of the South: Race and the Reconstruction of Southern Identity, 1865-1915 (Chapel Hill: University of North Carolina Press, 2014), 97-166.

49 For more on the Trans-Mississippi West during the Civil War and Reconstruction period, see Adam Arenson and Andrew R. Graybill, eds., Civil War Wests: Testing the Limits of the United States (Oakland: University of California Press, 2015); Andrew E. Masich, Civil War in the Southwest Borderlands, 1861-1867 (Norman: University of Oklahoma Press, 2016); and Megan Kate Nelson, The Three-Cornered War: The Union, the Confederacy, and Native Peoples Fight for the West (New York: Scribner, 2020).

50 Thomas D. Schoonover, "Dollars Over Dominion: United States Economic Interests in Mexico, 18611867," Pacific Historical Review 45, no. 1 (Feb. 1976): 23-45.

51 Jayes, Illusion of Ignorance, 9-21.

52 Lloyd J. Mercer, Railroads and Land Grant Policy: A Study in Government Intervention (Washington, DC: BeardBooks, 2002), 43.

53 The Texas and Pacific Railway: Its Route, Progress, and Land Grants (New York: Office of the Texas and Pacific Railway Co., 1872), 4.

54 "The Texas and Pacific Railway," 7.

55 "The Texas and Pacific Railway," 4.

56 “Tom Scott's Program," Ouachita Telegraph (Monroe, LA), Feb. 27, 1874, 1.

57 "Tom Scott's Program," 1.

58 "Memorial from New Orleans Chamber of Commerce," Memphis Daily Appeal, Mar. 17, 1874, 1.

59 "Memorial from New Orleans Chamber of Commerce," 1.

60 "Memorial from New Orleans Chamber of Commerce," 1.

61 “A Bounden Duty” Weekly Democratic Statesman (Austin, TX), June 26, 1873, 2.

62 "The International Road and Texan Statecraft," Weekly Democratic Statesman, Feb. 11, 1875, 1.

63 "The International Road and Texan Statecraft," 1.

64 "Let Us Build a Monument to This Legislature," Weekly Democratic Statesman, Mar. 4, 1875, 1.

65 "Let Us Build a Monument to This Legislature," 1.

66 "The Texas \& Pacific Railroad," Railroad Gazette (New York), Jan. 25, 1876, 62, 64. For more on Brown's political career, see Sam Davis Elliott, John C. Brown of Tennessee: Rebel, Redeemer, and Railroader (Knoxville: University of Tennessee Press, 2017).

67 "The Texas \& Pacific Railroad,"

68 "The Texas \& Pacific Railroad," 
69 "The Texas \& Pacific Railroad," 65.

70 "The Texas \& Pacific Railroad,"

71 For more on the Bourbon Democrats, see Michael Perman, The Road to Redemption: Southern Politics, 1869-1879 (Chapel Hill: University of North Carolina Press, 1984).

72 Kenneth Wayne Howell, Texas Confederate, Reconstruction Governor: James Webb Throckmorton (College Station: Texas A\&M University Press, 2008), 98-196.

73 James W. Throckmorton, Texas and Pacific Railway, Speech of Hon. Jas. W. Throckmorton of Texas, in the House of Representatives, 1 March 1877, together with the Report of the Hon. L. Q. C. Lamar, of Mississippi, Chairman of the Committee on Pacific Railroads, made to the House of Representatives, 24 January 1877 (Washington, DC, 1877), 19.

74 Throckmorton, Texas and Pacific Railway, 19.

75 Throckmorton, Texas and Pacific Railway, 19.

76 Throckmorton, Texas and Pacific Railway, 14.

77 Minutes of the Proceedings of the Commercial Convention held in the City of Memphis, Tennessee, May, 1869 (Memphis, TN: Southwestern Publishing Co., 1869), 88.

78 Minutes of the Proceedings of the Commercial Convention held in the City of Memphis, 88.

79 Southern Commercial Convention, Proceedings of the Southern Commercial Convention at its Annual Session at Cincinnati, Ohio, October 1870 (Cincinnati, OH: Committee of Arrangements of Cincinnati, 1871), 93.

80 Logan U. Reavis, Saint Louis: The Commercial Metropolis of the Mississippi Valley (Saint Louis, MO: Tribune Publishing Company, 1874), 36.

81 Reavis, Saint Louis, 36.

82 “Our Annual Report," New Orleans Republican, Sept. 1, 1876, 4.

83 "Our Annual Report," 4.

84 "Commerce between the Lakes and the South Seas," De Bow's Review (Washington, DC), May 1869, 380.

85 "Commerce between the Lakes and the South Seas," 380.

86 "The Southern Question," New York Tribune, May 15, 1874, 2.

87 "The Southern Question," 2.

88 "Railroads and the South," New York Tribune, Oct. 2, 1874, 1.

89 New York Tribune, Oct. 12, 1872, 6.

90 New York Tribune, Oct. 12, 1872, 6.

91 New York Tribune, Oct. 12, 1872, 6.

92 "Our Commerce with Mexico," Chicago Tribune, Dec. 9, 1873, 2.

93 Pletcher, Diplomacy of Trade, 109.

94 "Our Commerce with Mexico," Chicago Tribune, Dec. 9, 1873, 2.

95 "Our Commerce with Mexico," 2.

96 "Our Commerce with Mexico," 2.

97 "Our Commerce with Mexico," 2.

98 Hart, Empire and Revolution, 60.

99 Gregory P. Downs, "The Mexicanization of American Politics: The United States' Transnational Path from Civil War to Stabilization," American Historical Review 117, no. 2 (Apr. 2012): 387-409.

100 “The Financial Effect of Radical Bulldozing," Memphis Daily Appeal, Dec. 14, 1876, 2.

101 "No More Rebellion," New Orleans Republican, Nov. 16, 1876, 1.

102 "No More Rebellion," 1.

103 "No More Rebellion," 1.

104 "What Is 'Mexicanization'?," The Nation, Dec. 21, 1876, 365.

105 "What Is 'Mexicanization'?," 365.

106 "What Is "Mexicanization"?," 365.

107 The Nation, Apr. 5, 1877, 202.

108 Chicago Tribune quoted in New Orleans Daily Democrat, "Ended at Last," Apr. 26, 1877, 1.

109 "Ended at Last," 1.

110 Public Ledger, Mar. 1, 1877, 2.

111 "The Northern Democracy Opposing Pacification," National Republican (Washington, DC), Mar. $13,1877,2$.

112 "The Northern Democracy Opposing Pacification," 2. 
113 "Current Opinion," Chicago Daily Tribune, Apr. 24, 1877, 3.

114 "Current Opinion," 3.

115 "The Mexican Presidents," New York Times, Dec. 16, 1876, 4.

116 "Porfiriato" refers to the period during which Porfirio Díaz was president of Mexico. The Porfiriato began in 1876 and ended with the start of the Mexican Revolution in 1910-11. Throughout this period, Díaz was continuously reelected to office except between 1880 and 1884, when the presidency was held by his close political ally Manuel González. For more on Díaz’s domestic economic policies, see Steven B. Bunker, Creating Mexican Consumer Culture in the Age of Porfirio Díaz (Albuquerque: University of New Mexico Press, 2012); and Natalia Priego, Positivism, Science, and 'The Scientists' in Porfirian Mexico: A Reappraisal (Liverpool, UK: Liverpool University Press, 2016). For broader overviews of the Porfiriato, see Charles A. Hale, The Transformation of Liberalism in Late Nineteenth-Century Mexico (Princeton, NJ: Princeton University Press, 1989); and John Mason Hart, Revolutionary Mexico: The Coming and Process of the Mexican Revolution (Berkeley: University of California Press, 1987).

117 Pletcher, Diplomacy of Trade, 85.

118 San Marcos (TX) Free Press, Feb. 15, 1879, 1.

119 Hart, Empire and Revolution, 106-30. For more on the expansion of railroads during the early Porfiriato, see John H. Coatsworth, Growth against Development: The Economic Impact of Railroads in Porfirian Mexico (Dekalb: Northern Illinois University Press, 1981); and Daniel Lewis, Iron Horse Imperialism: The Southern Pacific of Mexico, 1880-1951 (Tucson: University of Arizona Press, 2007), 15-40.

120 Mercer, Railroads and Land Grant Policy, 46.

121 Hart, Empire and Revolution, 137.

122 Charles S. Campbell, The Transformation of American Foreign Relations, 1865-1900 (New York: Harper \& Row, 1976), 91.

123 Pletcher, Diplomacy of Trade, 77-78.

124 "The Texas Pacific R. R.," Mesilla (NM) Valley Independent, Oct. 20, 1877, 1.

125 "New Orleans Business," Brookhaven (MI) Ledger, Nov. 17, 1881, 2.

126 “An Occasion for Rejoicing," Dallas Daily Herald, Dec. 1, 1881, 4.

127 "An Occasion for Rejoicing," 4.

128 "An Occasion for Rejoicing," 4.

129 "Mexico-The Arrival of Senor Zamacona at New Orleans," New York Herald, Nov. 21, 1877, 7.

130 "Petty Jealousy," Chicago Tribune, June 8, 1883.

131 New York Herald quoted in Milwaukee (WI) Daily Sentinel, "Mexico Americanized-How Commerce Is Awakened and the Spirit of Self-Government Fostered," Feb.18, 1883, 7.

132 "Mexico Americanized," 7.

133 Juan Carlos Moreno-Brid and Jaime Ros, Development and Growth in the Mexican Economy: A Historical Perspective (Oxford: Oxford University Press, 2009), 49, 51.

134 "Railroads for Mexico," Chicago Tribune, Nov. 20, 1880, 4.

135 "Railroads for Mexico," 4.

136 "Railroads for Mexico," 4.

137 "Railroads for Mexico," 4.

138 This interpretation was common among newspapers located in regions with long-standing frontier cultures, such as the Midwest and far West. See for example "Mexican Colonization," Weekly Chillicothe (MO) Crisis, Mar. 24, 1881, 1; and “Colonists for Mexico," Sacramento Daily Record-Union, June 11, 1881, 8.

139 “Mexico," Dallas Daily Herald, Dec. 17, 1880, 3.

140 "Mexico," 3.

141 "The Monroe Doctrine," Chicago Tribune, Feb. 17, 1881, 4.

142 "The Monroe Doctrine," 4.

143 "Mexico," New York Herald, Aug. 17, 1879, 2.

144 "The American Doctrine," Chicago Tribune, June 16, 1881, 2.

145 "The American Doctrine," 2.

146 For just a few examples of how U.S. newspapers across the country enthusiastically reported Díaz's tour, see "Our Distinguished Visitors: Ex-President and Party Visit the Capital of Texas on Alamo Day," Weekly Democratic Statesman, Mar. 8, 1883, 4; "General Díaz-His Arrival at New Orleans-Kindly Feelings Expressed," Indianapolis (IN) Journal, Apr. 30, 1883, 3; "The Visit of Gen. Díaz, The Sun (New York), Apr. 9, 1883, 2; and "General Díaz," Omaha (NE) Daily Bee, Mar. 27, 1883, 4. 
Alys Beverton is a lecturer of history at Oxford Brookes University, UK. She has a $\mathrm{PhD}$ in history from University College London and a BA (hons) and MPhil in American studies from the University of Sussex, UK. Her research explores the cultural dimensions of U.S. foreign policymaking in the mid- to late nineteenth century. She is particularly interested in the relationship between popular conceptions of the U.S. national identity and Americans' evolving interpretations of their country's standing and role in the Western Hemisphere during this time.

Cite this article: Alys Beverton (2022) Transborder Capitalism and National Reconciliation: The American Press Reimagines U.S.-Mexico Relations after the Civil War, The Journal of the Gilded Age and Progressive Era 21, 40-61. https://doi.org/10.1017/S1537781421000578 